\title{
Learning Styles, does it Cause the Differences of Students Achievement?
}

\author{
Sarah Mustika Barokah ${ }^{1 *}$, Loviniantika Cahyaning Suseno ${ }^{2}$, Yosepha Kurniawati Deze Say ${ }^{3}$, Ali \\ Mustadi $^{4}$ \\ Universitas Negeri Yogyakarta, Jl. Colombo No.1, Sleman, Daerah Istimewa Yogyakarta 55281 \\ ${ }^{1}$ sarahbarokah89@gmail.com *; ${ }^{2}$ loviniantikacs@gmail.com; ${ }^{3}$ nounnasay@gmail.com; ${ }^{4}$ ali_mustadi@uny.ac.id \\ * corresponding author
}

\begin{tabular}{|c|c|}
\hline ARTICLE INFO & ABSTRACT \\
\hline \multirow[t]{3}{*}{$\begin{array}{l}\text { Article history } \\
\text { Received July 15, } 2019 \\
\text { Revised August 17, } 2019 \\
\text { Accepted November 19, } 2019\end{array}$} & $\begin{array}{l}\text { This research aims to examine the difference between the learning achievement } \\
\text { of students with learning styles visual, auditory, and kinesthetic in Sub-district } \\
\text { Sukun Malang. The type of this research was comparative quantitative. This re- } \\
\text { search population was all } 4 \text { th-grade students in Sub-district Sukun, which amount } \\
\text { to } 3250 \text { students, while the technique of sample retrieval used random cluster } \\
\text { sampling. Sample of this research amount to } 338 \text { of the } 4 \text { th-grade students from } 5 \\
\text { elementary schools in Sub-district Sukun. Data were collected by using learning } \\
\text { style questionnaires and documents of students learning achievement. Data analy- } \\
\text { sis of this research used quantitative statistics descriptive and analysis statistics } \\
\text { nonparametric using the Kruskal-Wallis Test. The result of this research showed } \\
\text { that the amount of significant value is } 0.688 \text {, higher than } 0.05 \text {, so it can be con- } \\
\text { cluded that there is no difference in thematic learning achievement between a } \\
\text { student who has visual, auditory, and kinesthetic learning styles. }\end{array}$ \\
\hline & $\begin{array}{l}\text { Penelitian ini bertujuan untuk menguji perbedaan antara prestasi belajar siswa } \\
\text { dengan gaya belajar visual, auditori, dan kinestetik di Kecamatan Sukun Malang. } \\
\text { Jenis penelitian ini adalah kuantitatif komparatif. Populasi penelitian ini adalah } \\
\text { semua siswa kelas } 4 \text { di Kecamatan Sukun, yang berjumlah } 3.250 \text { siswa, se- } \\
\text { dangkan teknik pengambilan sampel menggunakan cluster random sampling. } \\
\text { Sampel penelitian ini berjumlah } 338 \text { siswa kelas } 4 \text { dari } 5 \text { sekolah dasar di Keca- } \\
\text { matan Sukun. Data dikumpulkan dengan menggunakan angket gaya belajar dan } \\
\text { dokumen prestasi belajar siswa. Analisis data penelitian ini menggunakan statis- } \\
\text { tik kuantitatif deskriptif dan statistik analisis nonparametrik menggunakan Uji } \\
\text { Kruskal-Wallis. Hasil penelitian ini menunjukkan bahwa jumlah nilai signifikan } \\
\text { adalah 0,688, lebih tinggi dari } 0,05 \text {, sehingga dapat disimpulkan bahwa tidak ada } \\
\text { perbedaan dalam prestasi belajar tematik antara siswa yang memiliki gaya belajar } \\
\text { visual, auditori, dan kinestetik. }\end{array}$ \\
\hline & This is an open access article under the $\underline{\mathrm{CC}}-\mathrm{BY}$ license. \\
\hline
\end{tabular}

\section{Introduction}

Education is a conscious effort that is conducted to play roles in various aspects of life appropriately in the future. The goal of national education as stated in the Law Number 23 of 2003 concerning the National Education System is to develop the students' potential so that they will have faith, devotion to God, noble character, and be healthy, knowledgeable, capable, creative, independent, democratic and responsible citizens.
The realization of the goals can be seen through the success of teaching and learning activities in the classroom. (Gagne, 1970) states that students' achievement is a maximum achievement according to their ability of something they did, studied, comprehended, and applied. One of the parameters to determine students' achievement is learning outcomes in the form of scores gained by students and given by the teachers based on a 
proposed assessment mechanism. It is coherent with the ideas of (Partovi \& Razavi, 2019) contending that learning outcomes are the competencies achieved by each student after the learning process.

Learning and achievement, both in elementary and middle school, are worthwhile goals. For each student, the achievement of this goal depends on the complex reciprocity between a number of variables comprising students' background, prior learning, motivation, teacher characteristics, and quality of learning, classroom environment, parents' support, and some others. (Mudjiono, 2009) states that learning achievement is affected by external and internal factors. External factors cover teachers as a facilitator, for learning, learning infrastructure and facilities, assessment policies, school social environment, and school curriculums. Meanwhile, the internal factors include learning attitudes, motivation, concentration, processing materials, storing learning outcomes, exploring stored learning outcomes, achievement, confidence in the intelligence and learning success, learning habits or learning styles, and student aspiration.

As stated earlier, learning style is one of the internal factors, and it is in line with the study conducted by (Jilardi et al., 2011) which suggest that one of the factors affecting learning achievement is students' learning style. Learning styles have to be considered by educators as an appropriate learning style can lead students to be successful in learning. A person's ability to understand and comprehend a lesson is undoubtedly different from others. It is in accordance with (Winkel, 2007), who proposes that learning styles are a unique way of learning for students. Most students are not familiar with their learning styles. Hence, they have not been able to implement their learning styles optimally. Therefore, teachers are required to facilitate and assist the students in exploring their learning styles. Each student may have different learning styles, and whatever methods a student chooses, it shows the fastest and best way for each student to be able to absorb information outside him/her. (Bobbi \& Mike, 2016) state that learning styles are a combination of how a person absorbs, organizes, and processes information. Teachers must understand each type of learning style. Teachers who know their students' learning styles will be able to manage their classrooms to maximize the learning process. (Dryden \& Voss,
1999) propose three learning styles, namely visual, auditory, and kinesthetic. Furthermore, (Awla, 2014) found that people with visual learning styles learn well through what they see; people with auditory learning styles learn well through what they hear; and people with kinesthetic learning styles learn through motion and touch.

(Bobbi \& Mike, 2016) explain some of the characteristics of each learning style. The visual learning style has a characteristic of (a) behave differently, pay attention to detail, maintain appearance; (b) Remember better through pictures, prefer to read than to hear someone read for them; and (c) need holistic concepts and objectives and record details, remembering what is learned. The characteristics of auditory learning styles are: (a) easily losing focus; (b) talking in rhythmic patterns; (c) learning through listening, moving lips/making sound while reading, and (d) having internal and external dialogues. The characteristics of kinesthetic learning styles include: (a) touching people and standing close to others, frequently moving around; (b) learning by doing, pointing words while reading, responding physically; and (c) remembering while walking and looking.

Different learning styles will result in different learning achievements. It is inconsistent with the findings of a study conducted by (Mutoharoh, 2011), finding that learning styles have a positive effect on the achievement of learning sciences in the fourth-grade students of Purwosuman 1 Sidoharjo, Sragen. In addition, a similar study was conducted by (Sun et al., 2008) that revealed significant differences in learning achievement among students whose learning styles were accommodated. Therefore, understanding students' learning styles will facilitate both teachers and students during the teaching and learning process. Students will learn best if they understand their learning styles. It facilitates the students to comprehend the lesson, and it affects their achievement.

Each learning process needs an assessment to identify the students' understanding of the materials that have been learned. (Kennedy et al., 2008) show that the principle of good assessment is not only on the result but also in the learning process. The students' abilities can be measured during the learning process, through questioning and assessing the results of their works, observing the assignment results both in class and at home, supervising 
how the students read and respond to reading books, and assessing the results of the portfolio. A comprehensive assessment can be based on teacher's understanding on students' knowledge and skills, understanding on students' thinking level, each student's strengths, problems, and misconceptions, students' academic development over a certain period, students' personal assessment and responsibility in learning, and students' mastery of a topic or skill.

The study aims to identify the differences in learning achievement between students with visual, auditory, and kinesthetic learning styles. The formulation of the problem in this study is, 'Are there any differences in learning achievement between students with visual, auditory, and kinesthetic learning styles?'

\section{Method}

\section{A. Research Design}

The study is a comparative quantitative comparing students' achievement based on the learning styles, namely visual, auditory, and kinesthetic. The data were collected in one shoot.

\section{B. Research Setting}

This study was conducted in several elementary schools in Sukun, Malang City. It was conducted in September - December 2019.

\section{Research Population}

The population of this research was all fourth-grade students in Sukun, Malang City, with a total of 3250 students. The study used a significance level of $5 \%$ so that it involved 338 students from 5 elementary schools Sukun selected with cluster random sampling techniques. The researcher selected the same level of students, fourth-grade students.

\section{Data Collection}

The data were collected by distributing questionnaires and documentation of students' achievement. The questionnaire consisted of questions related to learning styles (Table 1).

Table 1. The scores for each response in the questionnaire

\begin{tabular}{ccc}
\hline No & Item & Scores \\
\hline 1 & Always & 5 \\
2 & Often & 4 \\
3 & Sometimes & 3 \\
4 & Rarely & 2 \\
5 & Never & 1 \\
\hline
\end{tabular}

The highest score out of the three learning styles based on students' responses to the questionnaire indicates the tendency of students' learning styles. Students who get similar scores for two or more learning styles or more, then their learning style will be based on the highest number of 'incorrect' or 'often' responses. The validity and reliability of the questionnaire were tested to students of SDN Oro-Oro Dowo 1. This elementary school was not taken as samples. The data were analyzed with SPSS 26, and the reliability was tested with the Cronbach's Alpha coefficient. Pearson Correlation was used to test the validity, which was based on the correlation of item values and total values. The validity criterion of the study was $5 \%(0.05)$, with the r-table values of 0.444 . The analysis showed that 7 out of 13 items in each learning style were dropped. The questionnaire was considered reliable because the $r$-count is higher than 0.444 .

Documentation of students' learning outcomes (learning achievement) referred to the midterm assessment (PTS) in the odd semester of the 2019/2020. The students' scores in the mid-term evaluation referred to themes 1 and 2 .

\section{E. Data Analysis Techniques}

The study used quantitative descriptive and parametric statistical analysis. The descriptive analysis described the frequency of each variable. The analysis of the hypothesis test can be done if it meets the requirements of normal data distribution and homogeneity. The hypotheses test used in the learning styles was the Kruskal-Wallis Test. The formula of the Kruskal-Wallis Test (Siegel, 1956) is as follows:

$$
\mathrm{H}=\frac{12}{\mathrm{~N}\{\mathrm{~N}+1\}} \sum_{j=1}^{k} \frac{R_{j}^{2}}{n_{j}}-3(\mathrm{~N}+1)
$$

Notes:

$$
\begin{aligned}
& \mathrm{k}=\text { number of samples } \\
& n_{j}=\text { number of cases in each }-\mathrm{j} \text { sample } \\
& \mathrm{N}=\sum n_{j}=\text { total of cases } \\
& R_{J}^{2}=\text { total rank for each }-\mathrm{j} \text { sample }
\end{aligned}
$$

To simplify the calculations using SPSS 26, with a hypothesis:

- $H_{o}$ : There is no difference in learning achievement between auditory, visual, and kinesthetic learning styles. 
- $H_{a}$ : There are differences in learning achievement between auditory, visual, and kinesthetic learning styles.

The criteria for rejecting $H_{o}$ are based on the significance values (less than $\alpha(0.05)$ ).

\section{Results and Discussions}

The variable data of learning style were gained through a questionnaire. Each type of learning style consisted of 6 variables, and the score for responses to each variable ranged from 1-5 (Table 2).

Table 2. Description of students' learning styles

\begin{tabular}{cccc}
\hline Notes & Visual & Auditory & Kinesthetic \\
\hline Maximum & 28 & 27 & 30 \\
Minimum & 10 & 11 & 14 \\
Means & 21.6 & 20.0 & 21.29 \\
Number of & 237 & 60 & 41 \\
students & & & \\
Percent & $70 \%$ & $18 \%$ & $12 \%$ \\
\hline
\end{tabular}

Based on the results of the analysis, the highest number was visual learning styles, with 237 students (70\%). Auditory and kinesthetic learning styles followed it with $60(18 \%)$ and $41(21 \%)$ students, respectively. The maximum number kinesthetic learning style is 30 and while visual and auditory learning styles reach 28 and 27, respectively. Meanwhile, the minimum number reaches 10,11 , and 14 for visual, auditory, and kinesthetic, respectively. The mean values of the visual learning style are higher (21.6) compared to kinesthetic (21.29) and auditory (20.0). Based on the description above, the number of students with visual learning styles is higher compared to those with auditory and kinesthetic learning styles.

Data on thematic learning achievement were gained by analyzing the results of the Mid-Semester Assessment (Odd Semester) in 2019/2020. The results of the Mid-Semester Assessment (PTS) for the fourth-grade students of theme 1 and 2 showed in Table 3.

Table 3. Distribution of students thematic learning achievement based on learning styles

\begin{tabular}{cccc}
\hline Description & Visual & Auditory & Kinesthetic \\
\hline Maximum & 96 & 97 & 93 \\
Minimum & 63 & 53 & 49 \\
Mean & 83.33 & 83.2 & 81.05 \\
Median & 84 & 84 & 83 \\
Modus & 84 & 84 & 79 \\
Standard Dev & 5.92 & 7.68 & 10.14 \\
Number of & 237 & 60 & 41 \\
students & & & \\
\hline
\end{tabular}

Based on Table 1.3, the maximum achievement value of students with visual learning styles is 96 , and the minimum value is 63. Then, for auditory learning styles, the maximum reaches 97 , and the minimum is 53 . The last, for kinesthetic learning styles, the maximum is 93 , and the minimum is 49 . The mean value of students with visual learning styles is 83.33 of 237 students. Then, for the students with an auditory learning style, it reaches 83.2 of 60 students. Meanwhile, for students with kinesthetic learning styles, the mean value is 81.05 of 41 students.

The normality test used KolmogorovSmirnov. The significance value of the visual learning style is 0.000 , while for auditory and kinesthetic learning styles; it reaches 0.020 and 0.000 , respectively. The three learning styles have significance values that are smaller than 0.05 . Therefore, it can be concluded that the three learning styles do not have a normal distribution (Table 4).

Table 4. Significance test

\begin{tabular}{cc}
\hline & Test Statistics $^{\mathbf{b}}$ \\
\hline & \multicolumn{2}{c}{ Thematic Learning Achieve- $_{\text {ment }}$} \\
\hline Kruskal-Wallis &, 747 \\
H & 2 \\
Df &, 688 \\
Asymp. Sig. & a. Kruskal Wallis Test \\
& \\
b. Grouping Variable: Learning Styles \\
\hline
\end{tabular}

Based on Table 1.4, the significance value of 0.688 is higher than 0.05 . Thus, $H_{o}$ is accepted, and $H_{a}$ is rejected. Therefore, it can be concluded that the variance of the visual, auditory, and kinesthetic group is the same.

The results showed that most students have a visual learning style (70\%). It is followed by auditory (18\%) and kinesthetic (12\%) learning styles. Then, the mean values of students' achievement were 83.33, 83.2, and 81.05 for visual, auditory, and kinesthetic, respectively.

The result of the hypothesis test using SPSS 26.0 for Windows shows that there is no difference in the thematic learning achievements between students with visual, auditory, and kinesthetic learning styles. It is consistent with the findings of studies conducted by (Amin \& Suardiman, 2016; Sun et al., 2008), suggesting that learning achievement based on students' learning styles does not show significant differences. Typically, the learning styles of each student's changes; therefore, learning styles 
cannot be used as a determinant factor of learning achievement (Leasa \& Corebima, 2017).

Some factors caused the absence of differences in learning achievement based on learning styles. First, elementary school students do not have a dominant learning style because they still focus on playing than learning. It is supported by the findings of (Leasa \& Corebima, 2017) that learning style is something dynamic, depending on the cognitive and mental development of each student and learning environment that can stimulate them to be more adaptive.

Students with visual learning styles understand the concept by observing. It is consistent with (Vaishnav, 2013), who found that students with visual learning styles find it easier to learn concepts through pictures, diagrams, flow charts, films, and demonstrations. In thematic learning, students with visual learning styles construct knowledge by reading textbooks that contain information in the form of text, images, and diagrams.

Meanwhile, students with auditory learning styles are more likely to learn by listening rather than reading or writing; they have abilities to produce symbols, words, or sentences by listening; like dialogue and music; and easily follow voice instructions (Kayalar \& Kayalar, 2017). One of the learning methods used in the 2013 Curriculum is the lecturing and discussion method. The first, if receptive, and the second, is productive skills for students with auditory learning styles to construct knowledge.

Students with kinesthetic learning styles prefer the learning process with various physical activities that facilitate them to obtain information. They like learning by directly involving all parts of their body (Gilakjani \& Ahmadi, 2011). In the thematic learning in the 2013 curriculum, practice, learning by doing, demonstration, role-playing, and experimentation are used for facilitating students with kinesthetic learning styles. In the learning process, learning styles are supported by the use of appropriate teaching materials and methods so that there are no significant differences in students' achievement.

Second, the teacher has been able to accommodate different learning styles through the application of thematic learning. The thematic learning emphasizes the active involvement of students' cognitive, affective, and psychomotor in the learning process.
One of the characteristics of thematic learning is providing hands-on experience to children. (Sukayati \& Wulandari, 2009) state that in thematic learning, the teacher plays a role as a facilitator, while the students' role is to find facts and information to develop their knowledge. The teacher accommodates the process of finding facts and information by providing opportunities for students to search for information through books (visual), discussion with peers and teachers (auditory), and learning by doing (kinesthetic). Teachers' sensitivity to different learning styles by using various approaches in teaching can help all students to achieve a maximum outcome (Singh, 2017).

This study has limitations, although researchers still strive to be maximized. The limitations cover (1) it is undeniable that there are so many determinant factors of learning achievement, while this study only focuses on learning styles (visual, auditory, kinesthetic). There is no difference in achievement among students with visual, auditory, and kinesthetic learning styles. Learning Styles (visual, hearing, and kinetic) cannot yet explain thoroughly the factors affecting the achievement of student thematic learning. (2) Assumptions are underlying the use of questionnaires as data collection instruments, but respondents who give answers according to actual conditions are difficult to control.

\section{Conclusion}

Based on the findings and discussion above, it can be concluded that there is no difference in the thematic learning achievement of the fourth-grade students with visual, auditory, and kinesthetic learning styles. The results show a significance value of 0.688 or higher than 0.05. It means that the hypothesis is rejected.

Based on the conclusions of this study that there is no difference in the thematic learning achievement among students with visual, auditory, kinesthetic learning styles, the teacher should be able to accommodate student learning styles to optimize students' achievement.

Based on the results of the study, the researcher suggests: (1) Other researchers to investigate the ways to increase the student's learning styles to maximize learning outcomes of other subjects; (2) The findings of this study are still far from perfection so that it needs further research related to the effect of learning 
styles towards elementary students' achievement.

\section{References}

Amin, A., \& Suardiman, S. P. (2016). Perbedaan prestasi belajar matematika siswa ditinjau dari gaya belajar dan model pembelajaran. Jurnal Prima Edukasia, 4(1), 12. https://doi.org/10.21831/jpe.v4i1.7688

Awla, H. A. (2014). Learning styles and their relation to teaching styles. International Journal of Language and Linguistics, 2(3), 241. https://doi.org/10.11648/j.ijl1.20140203.23

Bobbi, D. P., \& Mike, H. (2016). Qauntum learning. PT Mizan Publika.

Dryden, G., \& Voss, J. (1999). The learning revolution: to change the way the world learns. The Learning Web.

Gagne, R. M. (1970). The conditions of learning (Second Edi). Rinehart and Winston, Inc.

Gilakjani, A. P., \& Ahmadi, S. M. (2011). The effect of visual, auditory, and kinaesthetic learning styles on language teaching. International Conferences on Social Science and Huminity, 5, 469-472.

Jilardi, D. A., Mahyuddin, R., Elias, H., Daud, S. M., \& Shabani, J. (2011). Academic achievement of students with different learning styles. International Journal of Psychological Studies, 3(2). https://doi.org/10.5539/ijps.v3n2p186

Kayalar, F., \& Kayalar, F. (2017). The effects of auditory learning strategy on learning skills of language learners (students' views). IOSR Journal Of Humanities And Social Science (IOSR-JHSS, 22(10), 4. https://doi.org/10.9790/0837-2210070410

Kemendikbud. (2003). Undang-undang Republik Indonesia nomor 20 tahun 2003 tentang sistem pendidikan nasional.

Kennedy, L., Tipps, S., \& Johnson, A. (2008). Guiding children's learning of mathematics (Eleventh e). Thomson corporation.
Leasa, M., \& Corebima, A. D. (2017). Emotional intelligence among auditory, reading, and kinesthetic learning styles of elementary school students in Ambon-Indonesia. International Electronic Journal of Elementary Education, 10(1), 83-91. https://doi.org/10.26822/iejee.2017131889

Mudjiono, D. (2009). Belajar dan pembelajaran. PT. Rineka Cipta.

Mutoharoh, E. D. (2011). Pengaruh gaya belajar dan kesulitan belajar terhadap prestasi belajar ipa pada siswa kelas iv SD Negeri Purwosuman 1 Sidoharjo Sragen tahun pelajaran 2010/2011.

Partovi, T., \& Razavi, M. R. (2019). The effect of game-based learning on academic achievement motivation of elementary school students. Learning and Motivation, 68(June), 101592. https://doi.org/10.1016/j.lmot.2019.101592

Siegel, S. (1956). Nonparametric statistics for the behavioral sciences. McGraw-Hill Book Company,Inc.

Singh, V. (2017). Exploring the relationship between cognitive style and learning style with academic achievement of elementary school learners. Educational Quest- an International Journal of Education and Applied Social Sciences, 8(spl), 413-419. https://doi.org/10.5958/2230-7311.2017.00084.8

Sukayati, S., \& Wulandari, S. (2009). Pembelajaran tematik di SD (A. Waluyati (ed.)). PPPPTK Matematika.

Sun, K. T., Lin, Y. C., \& Yu, C. J. (2008). A study on learning effect among different learning styles in a Web-based lab of science for elementary school students. Computers and Education, 50(4), 14111422. https://doi.org/10.1016/j.compedu.2007.01.003

Vaishnav, R. (2013). Learning style and academic achievement of secondary school students. Voice of Research, 1(4), 1-4.

Winkel, W. S. (2007). Psikologi Pengajaran. Media Abadi. 